№ 3 (1), 2021

УДК 330.131.7:658

JEL D81

O. P. Podra, N. Ya. Petryshyn,

Lviv Polytechnic National University

\title{
THE ROLE OF MODERN MANAGEMENT TECHNOLOGIES IN ENSURING COMPETITIVENESS OF THE ENTERPRISE
}

https://doi.org/

(C) Podra O. P., Petryshyn N. Ya., 2021

The article is devoted to the study of modern management technologies in ensuring the competitiveness of the enterprise. A thorough study of theoretical positions and approaches to determining the technology and factors influencing the success of its implementation was conducted. The classification of innovative management decisions is generalized, which includes implementation, training, consulting, transfer and engineering, audit. It is established that the use of innovative technologies in management leads to increased productivity and flexibility of the enterprise; reducing the duration of the production cycle and / or increasing the speed of service provision; improving the quality of goods and services provided; expanding market presence. Peculiarities of using risk management technology in the economic activity of enterprises in the conditions of foreign economic operations are investigated. efficiency.

Keywords: management technology, risk management, enterprise, communications,

\section{Problem statement}

Modern technologies have a significant impact on the development of management in general and on the field of management decision-making. And in order to provide an effective organization functioning, to provide the goals achievement, it is necessary to make balanced, optimal, rational management decisions. Thus, the study of existing management technologies in terms of management decisions becomes relevant at the present stage in order to ensure the survival of the enterprise in a changing environment, as well as to achieve a high level of competitiveness.

\section{Research relevance}

In the modern economic realities of economic activity there is a difficulty in predicting and forecasting the development of the external environment, in such conditions, deepening theoretical and practical developments related to the use of modern management technologies related to economic risk management becomes more relevant. It should be noted that there is no comprehensive system of enterprises' risk assessment and management, insufficient consideration of their industry specifics, which is why the need to study modern management technologies to ensure the competitiveness of enterprises, including risk management technology becomes an object for scientific research.

\section{Aim and scope}

The purpose of the research is to study the issues and features of management decisions making in enterprise management technology in order to ensure competitiveness in the market and the ability to respond quickly to changes in the environment. The main tasks include the following: definition of the content and essence of the concepts: "technology", "management technology"; to determine the features of the process of forming a management decision in management technology; generalize the classification of 
innovative management decisions; to study the features of the use of risk management technology in order to ensure the efficiency of economic activity of enterprises.

\section{Literature rewiev}

We may find a lot scientific studies devoted to the problems and peculiarities of managerial decision-making in the modern scientific literature. A significant contribution to the development and solution of the theory of management decisions was made by domestic and foreign scientists: O.M. Ovdiyuk [1], G.V. Luta, I.A. Pavlenko [2], V.G. Sobolev [3], I.M. Chmutova [4], V.G. Kozachenko [5] and others. However, with the strengthening of the role of management decisions under conditions of scientific and technological progress and the growing number of scientific papers in this field, there is a need to study the features of management decisions making in modern management technology based on thorough theoretical research and development of risk management technology of the enterprises that hold foreign economic activity.

\section{The main research}

Technology is a set of methods of processing, manufacturing, changing the state, properties, shape of raw materials, materials or semi-finished products, carried out in the process of manufacturing products [3]. Thus, "technology" is an approach that combines a specific method of achieving the target aggregate result in any field.

At the same time, it should be noted that the concept "technology" in the field of enterprise management requires a detailed study and thorough analysis of approaches to its definition. The management process involves the implementation of management functions, which in modern interpretation are: collection and analysis of information, planning, organization and motivation, accounting, control and analysis, regulation. Each of these functions can be performed through a set of different management procedures, provided by the appropriate tools. Management technology - a purposeful, ordered, coordinated set of management procedures that are implemented within the management functions and provided by the choice of appropriate tools and management methods [4]. Thus, the key factors for technology in management are the information environment and the method of obtaining and converting the information that is needed to perform the management function.

From the point of view of managerial work, this concept is interpreted as follows - technology is any means of converting source materials to obtain the desired results. As the subject and, accordingly, the source material of management work is information, so the technology of management can be a set of methods for processing management information in order to develop, make and implement management decisions. Thus, the purpose of management technology is a management process that must achieve the goal.

Management technology is understood as the following - it is a structured sequence of interconnected management procedures and operations, the implementation of which is aimed at the implementation of management functions, accompanied by management decisions and provided with certain methods and techniques. Management technologies provide an opportunity, in accordance with the chosen approach to enterprise management, to implement management principles in management processes, use management methods, organize management processes. Management technology reflects the content of management, the processes of movement and processing of information, determines the composition and procedure of management work, during which information is transformed and creates grounds for influencing the managed object to transform it to the desired state, allows rational interaction of structural units and individual performers in the management process [5]. Thus, management technology is a set of methods, approaches, procedures, techniques of management work, which are entrusted to managers at all levels, aimed at achieving goals in part of effective management decisions with cyclical character providing.

Modern management is $80 \%$ technology, and management efficiency depends on how many professionals are able to master it and learn to use it. The technology of management should be understood 
as a way of carrying out activities and the ability to rationally divide it into procedures and operations, with their subsequent coordination and synchronization, the choice of optimal means and methods of implementation; means of translating the abstract language of science into a specific language to achieve the goals $[6, \mathrm{p} .21]$. Thus, management technology involves a combination of techniques, methods and tools, both formal and informal, which are aimed at the logical decomposition of the management system into structural units, which are carried out in a certain sequence in order to achieve the goal. In a part of management decisions in management technology, the following requirements can be identified: the selection, development and implementation of management decisions should be localized at that level of the hierarchical structure, where the necessary information is concentrated for the successful solution of a managerial task.

As it was established, the crucial factor in management technology is played by the human factor and the ability to communicate. Consider several modern approaches to defining the essence and content of the concept of "communication". Thus, in theoretical research, communication is interpreted either as an action (a one-way process of transmitting signals without feedback), or as an interaction (two-way process of information exchange). Also, communication is associated primarily with information exchange and is understood as a joint communicative activity of its participants, aimed at achieving specific goals. It is impossible without the presence of its main elements (addressee, message, encoding / decoding, channel, medium, etc.), which affect the quality and outcome of information exchange [7]. Thus, communication is a kind of process of information transfer from one source to another, which can be carried out in any convenient form for the participants of this process.

Communication processes in the field of management have the specificity and feature. Thus, according to O. Babchynska, communication in management is defined as the process of exchanging information between employees and the environment in order to solve certain problems. It was noted that when considering the communication exchange of information at the enterprise, in main cases mean people who communicate directly in person or in a group, as well as their telephone conversations, correspondence and reporting, etc., but it should be taken into account that communication involves various forms of relationships between people based on different types of interaction that are aimed at achieving the goals of the enterprise. They are a special form of influence on employees and the environment [8]. Thus, the effectiveness of management decisions in the technology of enterprise management depends on the quality of construction of the communication process and, accordingly, the transmission and receipt of the necessary information.

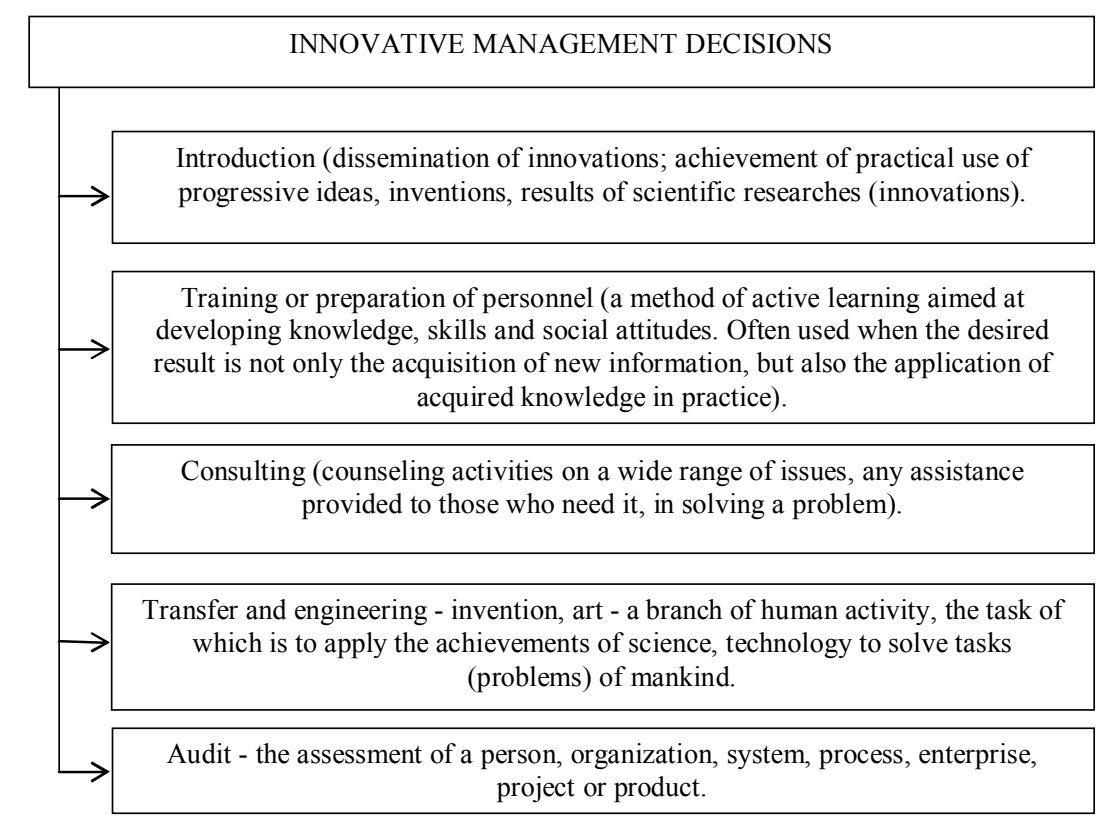

Fig. 1. Innovative management decisions [2, c. 299] 
The analysis of scientific sources devoted to the researched subject gives the bases to make the generalized classification of innovative management decisions which is resulted in fig. 1, in particular introduction, training or preparation of personnel, consulting, transfer and engineering, audit.

The content of the concept of "innovative technologies in enterprise management", so they can be defined as [2, p. 300]:

- new concepts for enterprise management;

- new ideas for the development of the enterprise and their implementation;

- new channels of search and communication to improve work with suppliers, customers, employees;

- new solutions in enterprise management.

Innovative technologies are unique, but over time, during their constant use, they are transformed and defined as conventional technologies. Novelty is a temporal characteristic of any tangible or intangible thing created by man, so at a certain time each technology was innovative.

The use of innovative technologies in management leads to:

- increase the productivity and flexibility of the enterprise;

- reducing the duration of the production cycle and / or increasing the speed of service provision;

- improving the quality of goods and services provided;

- expanding market presence.

The creation, development and application of innovative technologies can be the basis for the success of the enterprise. Innovative technologies not only serve as an important competitive tool, but also play an important role in improving the efficiency of the enterprise.

Modern management technologies include a customer relationship management system; benchmarking; staff recruitment audit; strategic planning and strategic management; outsourcing; balanced scorecard, etc.

At the same time, in the current dynamic conditions of market environment change, the activity of domestic enterprises is inextricably linked with probable risks and losses. In such cases, there is a need to implement a certain mechanism or risk and loss management technologies. Such technology becomes a risk management, which is widely used in the activities of both domestic and foreign enterprises, especially in the context of foreign economic transactions.

Risk management technology is a technology of risk management that arises in the process of economic activity of the enterprise. This ensures the implementation of the process of influencing the business entity, which allows to cover a significant range of probable risks. The main result of the application of risk management technology is to reduce the possible impact and minimize the degree of risk to the lower limit. The probability of occurrence of risk is determined, on its basis the strategy which determines the future behavior of the business entity in the conditions of occurrence of risk is accepted and developed. The tools used in the process of implementing risk management technology provide a real opportunity to predict the probability of risk and apply appropriate measures to reduce the negative effects on the consequences of risk events.

Risks management technology involves the use of organizational, economic and technological actions that identify potential risks, determine their causes, sources of origin, activation factors. Risk assessment contributes to the development of effective measures for timely identification of losses and their prevention.

Risk management technology will allow the management of enterprises especially those that hold foreign economic activity to apply adequate to situations and conditions ways to solve risk management problems. Consistent implementation of basic risk management operations is important:

- determining the nature of risks, ie what they are related to, how they manifest themselves;

- identification, analysis and assessment of the degree of risk;

- identification of threatening effects of risk;

- risk monitoring;

- providing management communications for risk management. 
The effectiveness of risk management technology in the management of enterprises that have foreign economic operations is determined by how wide the range of risks it can cover, as well as a set of risk management methods that can be used in management to form management decisions to minimize the impact and consequences of risks. Effectiveness is determined by strategic measures and tactical actions in the event of a specific situation associated with the occurrence of risks and losses. The use of management technology, which allows to manage risks, creates conditions for the operation of the enterprise in conditions of increased uncertainty and riskiness of the external environment.

The introduction of risk management technology in management will ensure:

- prevention of probable risks;

- minimization of losses and damages in cases where the risk still occurs;

- maximization of revenues and additional profits that will be provided in case of successful risk management.

The main requirements for the implementation of the recommended risk management technology:

- acceptance of the probability of risk appearance;

- adequate response to the risk that has arisen, in accordance with the conditions of the specific situation;

- ensuring the minimization of the degree of risk, its consequences and costs incurred;

- ensuring complete coverage of probable risks;

- maximization of risk management tools.

The application of risk management involves the implementation of a standard set of general management functions linked to the providing of management of a specific object, ie risk.

Risk planning in the process of their management, in order to ensure the process of making the necessary management decisions, is to use expert or statistical methods to predict the likelihood of risk.

The organization provides an opportunity to implement in practice the operation of the enterprise specific measures or program of measures for risk management, ie ensuring its reduction.

Motivation of employees who will be involved in the process of implementing risk management technology should ensure interest in obtaining real results.

Control allows you to compare the actual state of activities aimed at reducing or avoiding risks, with the planned ones. At the same time, the developed measures for risk management, their effectiveness, results obtained, costs incurred, etc. will be analyzed.

The regulation will provide an opportunity to eliminate deviations in the parameters of risk management.

All risk management activities should be coordinated and should ensure consistency of activities at different levels and in different areas of enterprise management. Risk management should be implemented by managers with an understanding of the main purpose and results of such activities.

In our opinion, the postoperative sequence of risk management technology for enterprises engaged in foreign economic activity should include the following stages:

1) establishing the purpose and objectives of risk management;

2) identification of existing problems of the probability of risk in the context of foreign economic transactions;

3) identification of the probability of possible risks;

4) quantitative and qualitative assessment of probable risks;

5) determination of the optimal method of risk management (preservation, equalization, reduction, avoidance, transfer);

6) decision-making that concerns risk management;

7) evaluation of the results obtained in relation to risk management.

At the stage of risk identification, the probability of their occurrence is determined, ie with what probability the risk events will occur. The conditions of the increased risks, sizes of their negative influences on activity of the enterprises are identified. 
In order to form an array of necessary information to identify risks should use the results of the analysis of enterprise reports, the results of surveys of managers, if necessary, to involve external consultants and experts.

When assessing the probable risks, several scenarios for the future occurrence of adverse events and situations should be developed, and the probable incurred losses should be calculated. In the case where losses have already been incurred, the results of assessing the causes of their occurrence can identify existing risks.

However, risk management is aimed at anticipating the events of risk. In the quantitative assessment of risks, risk indicators that are integral in nature are calculated, the amount of probable losses, indicators of risk levels, etc. are determined. Analytical, expert methods, modeling and statistical methods should be used to analyze and assess the risks of enterprises under the conditions of foreign economic operations. The following methods can be used to regulate or manage risk: conservation, equalization, reduction, provisioning, avoidance, transfer (external insurance or distribution).

In our opinion, in order to optimize the risk, it is appropriate to use different combinations of the proposed methods, but it should be noted that the key selection criteria should be the optimal ratio between the allowable level of risk and the amount of costs associated with its prevention that is, it is necessary to be able to find a balance between the expected benefit and the threat of losses / losses. In such a situation, it is necessary to make an optimal and rational management decision that involves the choice of a specific type of risk impact: avoidance, transfer, risk reduction, etc.

\section{Conclusions}

In modern dynamic environment conditions change, the activity of economic entities is associated with uncertainty and risk, and therefore require constant monitoring and adjustment measures to maintain market position and competitiveness. Under such conditions, it is necessary to use acceptable and sound modern management technologies, including risk management technology, which can be defined as a set of management actions to identify, prevent, analyze, regulate, neutralize risks. The proposed technology of risk management of enterprise management in the conditions of foreign economic operations provides for the consistent implementation of stages that will ensure the neutralization of risk, and the exit of the enterprise from the risky situation with the least losses.

\section{Prospects for further research}

The prospect of further research is to find new tactical and strategic decisions for risk management of enterprises that hold foreign economic activity under conditions of the dynamics changes of the external environment.

\section{Список літератури}

1. Овдіюк О.М. Управлінські рішення в технології менеджменту підприємств / О.М. Овдіюк // Ефективна економіка. - 2019. - № 6. [Електронний ресурс]. - Режим доступу: http://www.economy. nayka.com.ua/?op $=1 \& \mathrm{z}=7120$

2. Люта Г.В. Вплив інноваційних технологій на систему управління підприємством / Г.В. Люта, І.А. Павленко // [Електронний ресурс]. - Режим доступу: http://www.economyandsociety.in.ua/eng/journal-12/19stati-12/1325-lyuta-g-v-pavlenko-i-a

3. Соболев В.Г. Визначення сутності поняття «Технологія менеджменту персоналу» / В.Г. Соболев // Теорія та практика державного управління. -2016. - 2(53). [Електронний ресурс]. - Режим доступу: http://www.kbuapa.kharkov.ua/e-book/tpdu/2016-2/doc/4/405.pdf

4. Чмугова І.М. Сугність технології управління та їі ключові ознаки / I.М. Чмутова // Науковий вісник Чернівецького університету: зб. наук. праць. Серія «Економіка». - Вип. 710-711. - Чернівці: ЧНУ, 2014. - С. 70-75.

5. Козаченко В.Г. Технологізація управлінської діяльності: зміст та призначення / В.Г. Козаченко // Економіка і регіон. - 2016. - № 3 (58). - ПолтНТУ. - С. 37-40.

6. Менеджмент по нотам: Технология построения эффективных компаний / Под ред. Л. Ю. Григорьева. - М.: Альпина Паблишерз, 2010. - 692 с. 
7. Чорнобай О.Л. Природа, структура і типологія спілкування (комунікації) у професійній діяльності юриста / О.Л. Чорнобай // Вісник Національного університету «Львівська політехніка». Юридичні науки. 2015. - № 824. - С. 347-356. [Електронний pecypc]. - Режим доступу: http://nbuv.gov.ua/UJRN/ vnulpurn_2015_824_57

8. Бабчинська O.I. Комунікаційний процес в управлінні: основні положення / O.I. Бабчинська // Ефективна економіка. - 2018. - № 9. [Електронний ресурс]. - Режим доступу: http://www.economy. nayka.com.ua/?op=1\&z=6539

\section{Reference}

1. Ovdiiuk O.M. (2019). Upravlinski rishennia v tekhnolohii menedzhmentu pidpryiemstv / O.M. Ovdiiuk [Management decisions in enterprise management technology]. Efektyvna ekonomika. 2019. No 6. Retrieved from: http://www.economy.nayka.com.ua/?op=1\&z=7120

2. Liuta H.V., Pavlenko I.A. (2017). Vplyv innovatsiinykh tekhnolohii na systemu upravlinnia pidpryiemstvom [The impact of innovative technologies on the enterprise management system]. Retrieved from: http://www.economyandsociety.in.ua/eng/journal-12/19-stati-12/1325-lyuta-g-v-pavlenko-i-a

3. Sobolev V.H. (2016). Vyznachennia sutnosti poniattia «Tekhnolohiia menedzhmentu personalu» [Defining the essence of the concept of "Personnel Management Technology"]. Teoriia ta praktyka derzhavnoho upravlinnia, 2(53). Retrieved from: http://www.kbuapa.kharkov.ua/e-book/tpdu/2016-2/doc/4/405.pdf

4. Chmutova I.M. (2014). Sutnist tekhnolohii upravlinnia ta yii kliuchovi oznaky [The essence of control technology and its key features]. Naukovyi visnyk Chernivetskoho universytetu: zb. nauk. prats. Seriia «Ekonomika», vol. 710-711, 70-75.

5. Kozachenko V.H. (2016). Tekhnolohizatsiia upravlinskoi diialnosti: zmist ta pryznachennia [Technologization of management: content and purpose]. Ekonomika i rehion, 3 (58), 37-40.

6. Hryhoreva L. Yu. (2010). Menedzhment po notam: Tekhnolohyia postroenyia эffektyvnblkh kompanyi [Management by Notes: Technology for Building Effective Companies]. M.: Alpyna Pablysherz.

7. Chornobai O.L. (2015). Pryroda, struktura i typolohiia spilkuvannia (komunikatsii) u profesiinii diialnosti yurysta [The nature, structure and typology of communication in the professional activity of a lawyer]. Visnyk Natsionalnoho universytetu "Lvivska politekhnika". Yurydychni nauky, No 824, 347-356. Retrieved from: http://nbuv.gov.ua/UJRN/vnulpurn_2015_824_57

8. Babchynska O.I. (2018). Komunikatsiinyi protses $\mathrm{v}$ upravlinni: osnovni polozhennia [Communication process in management: basic provisions]. Efektyvna ekonomika, No 9. Retrieved from: http://www.economy.nayka.com.ua/?op=1\&z=6539

О.П. Подра, Н.Я.Петришин

Національний університет «Львівська політехніка»

\section{РОЛЬ СУЧАНИХ УПРАВНІНСЬКИХ ТЕХНОЛОГІЙ У ЗАБЕЗПЕЧЕННІ КОНКУРЕНТОСПРОМОЖНОСТІ ПІДПРИЕМСТВА}

(C) Подра О.П., Петришин Н.Я., 2021

Стаття присвячена дослідженню сучасних управлінських технологій у забезпечені конкурентоспроможності підприємства. Здійснено грунтовне дослідження теоретичних положень та підходів до визначення управлінської технології та чинників, що впливають на успішність її реалізації. Узагальнено класифікацію інноваційних управлінських рішень, до складу якої входять впровадження, тренінг або підготовка кадрів, консалтинг, трансферт та інжиніринг, аудит. Встановлено, що використання інноваційних технологій в управлінні призводить до підвищення продуктивності і гнучкості підприсмства; скорочення тривалості виробничого циклу та/або підвищення швидкості надання послуг; поліпшення якості товарів та послуг, що надаються; розширення присутності на ринку. Встановлено, що інноваційні технології управління включать систему управління взаємовідносинами з кліснтами; бенчмаркінг; аудит залучення персоналу; стратегічне планування та стратегічне управління; аутсорснг; збалансовану систему показників та ін. 
Досліджено особливості використання технології ризик-менеджменту у діяльності підприсмств в умовах здійснення зовнішньоекономічних операцій. Технологія ризикменеджменту - це технологія управління ризиками, що виникають в процесі здійснення господарської діяльності підприємства. Основний результат застосування технології ризикменеджменту полягає у скороченні можливого впливу і мінімізації ступеня ризику до нижньої межі. Запропоновано послідовне здійснення основних операцій з управління ризиками, яке спрямоване на визначення сутності ризиків, з'ясування того, з чим вони пов'язані, як вони проявляються; виявлення, аналіз та оцінка ступеня ризику; виявлення загрозливих наслідків ризику; моніторинг ризиків; забезпечення управлінських комунікацій для управління ризиками. 3 метою оптимізації ризику доречно використовувати різноманітні комбінації методів управління ризиками, водночас слід зауважити, що ключовим критерісм вибору повинно бути оптимальне співвідношення між допустимим рівнем ризику та обсягом витрат, які пов'язані із його попередженням, тобто необхідно вміти віднайти баланс між очікуваною вигодою та загрозою збитків/втрат.

Ключові слова: управлінська технологія, ризик-менеджмент, підприємство, комунікації, ефективність 